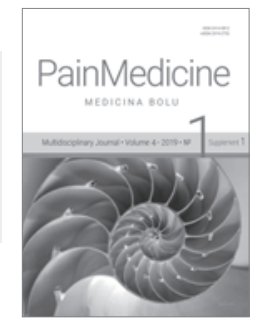

DOI: 10.31636/pmjua.t2.4

\title{
Мікросудинна декомпресія при рецидивах класичної тригемінальної невралгії після перкутанних втручань на трійчастому вузлі
}

\author{
Набойченко А. Г., Федірко В. О. \\ ДУ "Інститут нейрохірургії ім. акад. А. П. Ромоданова НАМН України", Київ, Україна
}

Актуальність. Процедури перкутанної ризотомії (ПР) в лікуванні класичної тригемінальної невралгії (КТН), за своєї достатньої ефективності, мають значний відсоток невдач та рецидивів болю. Вибір іншого втручання дуже складний, оскільки дані щодо лікування рецидивів КТН обмежені.

Мета дослідження. Дослідити, чи впливають раніше проведені перкутанні втручання на ефективність та безпечність "золотого стандарту” лікування КТН - мікросудинної декомпресії (МСД).

Матеріали та методи. Ретроспективний аналіз 28 послідовних випадків проведення МСД з приводу рецидиву КТН після ПР за період 2015-2016 рр. Категоризація даних та статистична обробка. Контрольна група 66 МСД у пацієнтів з КТН без будь-яких попередніх процедур. Використовувались шкали BNI для болю (BNI PS) та заніміння (BNI NS).

Результати дослідження та їх обговорення. Інтраопераційні знахідки: атрофія та деколорація трійчастого нерва - в 9 випадках (32\%); щільні арахноїдальні злуки 3 деформацією корінця - в 13 випадках (46,7\%); “молочне” помутніння павутинної оболони - в 5 (17,8\%); в одному випадку конфлікт не виявлено (3,6\%). Середній післяопераційний бал за шкалою BNI PS склав 2,21 і статистично не відрізнявся від контрольної групи - 1,95. Під час останнього контролю бал BNI PS був нижчим у групі виключно МСД (1,43 проти 2,43; P = 0,0006; 95 \% ДІ 0,59181,9987). BNI NS та інші показники нейропатії були вищими в групі ПР (2,5 проти 1,3; P<0,0001; $95 \%$ ДІ 0,6697-1,6541). Серед них $100 \%$ мали клінічно суттеву нейропатію та $57 \%$ мали дизестезії, на відміну від $27 \%$ та $7 \%$ відповідно в групі виключно МСД. Поява або погіршення симптомів нейропатії спостерігались у 5 пацієнтів (17,9\%). Додаткові ризики розвитку нейропатичних проявів ймовірно обумовлені деструктивним характером перкутанних втручань.

Висновки. Процедура МСД, як більш патогенетично обгрунтована, лишається втручанням вибору для пацієнтів із рецидивами КТН після раніше проведених ПР. Результати у цієї категорії пацієнтів гірші, ніж після первинної МСД.

Перспективи подальших досліджень. Багатоцентрові дослідження 3 мультифакторним аналізом великих масивів даних.

Ключові слова: невралгія трійчастого нерва, тригемінальна невралгія, мікросудинна декомпресія, мікроваскулярна декомпресія, рецидив невралгії.

Конфлікт інтересів. Відсутній. 